\title{
PENINGKATAN HASIL BELAJAR SISWA PADA MATA PELAJARAN AGAMA HINDU MELALUI MODEL PEMBELAJARAN PRACTICE REHEARSAL PAIRS SISWA KELAS XII SMA NEGERI 1 RANDANGAN \\ (Improvement of student learning outcomes in hindu religion learning through practice rehearsal pairs learning model for class XII students of SMA Negeri 1 Randangan)
}

\author{
Negah Buderasa \\ Sekolah Menengah Atas Negeri 1 Randangan \\ Jl. Trans Sulawesi Motolohu, Kecamatan Randangan \\ Kabupaten Pohuwato, Provinsi Gorontalo, Kode Pos 96268 \\ Email: lasamulafai@gmail.com
}

\begin{abstract}
ABSTRAK
Tujuan penelitian ini adalah untuk meningkatkan aktivitas belajar siswa Kelas XII SMA Negeri 1 Randangan melalui pembelajaran model Practice Rehearsal Pairs dan meningkatkan kemampuan pemecahan masalah dalam diskusi oleh siswa kelas XII SMA Negeri 1 Randangan. Teknik pengumpulan data dilakukan dengan observasi dan tes tertulis. Dari hasil penelitian, aktivitas belajar siswa pada siklus I, 2 kali pertemuan mengalami peningkatan. Hal ini dapat dilihat dari siklus I pertemuan pertama, siswa yang mendapatkan nilai dalam kisaran indikator B pada siklus I pertemuan pertama berjumlah 9 orang siswa atau hanya mencapai $40,9 \%$ sedangkan pada siklus 1 pertemuan kedua menjadi 11 orang siswa atau $50 \%$ dan jumlah siswa pada siklus I pertemuan pertama yang mendapatkan nilai dalam kisaran indikator $\mathrm{C}$ berjumlah 5 orang atau $22,8 \%$ pada siklus I pertemuan kedua hanya tersisa 4 orang atau sekitar $18,1 \%$ saja. Kegiatan belajar mengajar ada siklus I pertemuan kedua telah mencapai target yang ditentukan yaitu $75 \%$ menjadi $81,9 \%$ bahkan melampaui target. Hal ini dapat dilihat pada peningkatan hasil belajar siswa dan kegiatan belajar mengajar yang lebih efektif dari siklus I pertemuan pertama.
\end{abstract}

Kata Kunci: Hasil belajar; model pembelajaran; practice rehearsal pairs

\begin{abstract}
This study aimed to increase the learning activities of the XII grade students of SMA Negeri 1 Randangan by learning the Practice Rehearsal Pairs model and improving the problemsolving skills in class XII students of SMA Negeri 1 Randangan. Data collection techniques were carried out by observation and written tests. From the research results, student learning activities in cycle I, two meetings have increased. It can be seen from the first cycle of the first meeting, students who get scores in the range of indicator B in the first cycle of the first meeting amounted to 9 students or only reached $40.9 \%$, while in the first cycle, the second meeting became 11 students or $50 \%$ and the number of students. The first meeting that got a value in the range of indicator $\mathrm{C}$ was five people or $22.8 \%$ in the first cycle. The second meeting was only four people or around $18.1 \%$. In the first cycle of the second meeting, teaching and learning activities had reached the specified target, namely $75 \%$ to $81.9 \%$, and even exceeded the target. It showed improving student learning outcomes and more effective teaching and learning activities from the first meeting cycle.
\end{abstract}

Keywords: Learning outcomes; Learning model; Practice Rehearsal Pairs 


\section{PENDAHULUAN}

Slameto (2010) menyatakan bahwa belajar ialah suatu proses usaha yang dilakukan seseorang untuk memperoleh suatu perubahan tingkah laku yang baru secara keseluruhan, sebagai hasil pengalamannya sendiri dalam interaksi dengan lingkungannya. Berdasarkan hasil observasi di SMAN 1 Randangan diketahui bahwa pelaksanaan pembelajaran pada mata pelajaran Agama Hindu, proses pembelajaran selama ini berlangsung menggunakan metode pembelajaran dengan metode ceramah yaitu guru lebih mendominasi dalam pembelajaran (teacher centered). Sehingga siswa akan cenderung bersikap pasif dan tidak bisa mengoptimalkan keahlian yang dimiliki. Siswa juga beranggapan bahwa Model pembelajaran Agama Hindu Cenderung membosankan, maka hal ini dapat mengakibatkan nilai hasil belajar siswa dalam pelajaran Agama Hindu tidak sesuai harapan, sehingga nilai hasil belajar siswa rendah, hal ini ditandai dengan nilai semester 2 yaitu sebanyak $50 \%$ siswa tidak tuntas (data selengkapnya ada pada Lampiran. Kriteria ketuntasan mininal untuk mata pelajaran Agama Hindu adalah 75. Ada beberapa faktor yang menyebabkan nilai hasil belajar siswa belum sesuai dengan harapan diantaranya adalah rendahnya kualitas pembelajaran yang ditandai dengan belum diterapkannya model pembelajaran. Hal tersebut dipersulit lagi oleh suatu kondisi guru mendominasi kegiatan pembelajaran. Pembelajaran hanya sebatas pada teori saja dan kurang mengembangkan kemampuan afektif dan psikomotor siswanya. Salah satu upaya yang bisa dilakukan yaitu dengan menggunakan model pembelajaran Practice Rehearsal Pairs. Model pembelajaran ini merupakan salah satu model pembelajaran aktif yang mampu mengarahkan atensi siswa terhadap materi yang dipelajarinya.

Menurut Melvin L Silberman, salah satu cara yang paling efektif dan efisien untuk meningkatkan hasil belajar adalah dengan membagi peserta berpasangpasangan dan menyusun partner belajar. Suatu mata pelajaran benar-benar dikuasai hanya apabila seorang siswa mampu mengajarkan kepada siswa lain. Model pembelajaran practice rehearsal pairs memberikan kesempatan kepada siswa untuk saling mengajar dengan siswa yang lain. Dengan diterapkannya model pembelajaran practice rehearsal pairs ini, diharapkan dapat membuat siswa akan lebih berpartisipasi aktif dalam kegiatan pembelajaran serta dapat meningkatkan hasil belajar siswa yang semula hanya sebatas kriteria ketuntasan minimal, sehingga dapat mencapai hasil yang diharapkan. Oleh sebab itu, perlu dikaji 
dan diteliti lebih mendalam apakah penerapan model pembelajaran Practice Rehearsal Pairs dapat meningkatkan hasil belajar siswa. Sehingga diambil judul penelitian "Peningkatan Hasil Belajar Siswa Pada Mata Pelajaran Agama Hindu Melalui Model Pembelajaran Practice Rehearsal Pairs Siswa Kelas Xii Sma Negeri 1 Randangan”.

\section{METODE PENELITIAN}

\section{Lokasi Dan Waktu Penelitian}

Penelitian ini merupakan penelitian tindakan kelas yang dilaksanakan di kelas XII SMAN 1 Randangan. Penelitian ini direncanakan dalam waktu maksimal 3 bulan mulai dari pengumpulan data, pengolahan data, dan penyusunan hasil penelitian.

\section{Tahap Penelitian}

Tahap Persiapan, Tahap Pelaksanaan Tindakan ini dilaksanakan dalam beberapa siklus dimana dalam setiap siklus dilaksanakan dalam 2 kali pertemuan.

Model pembelajaran Practice Rehearsal Pairs

Dengan demikian dapat disimpulkan bahwa Practice Rehearsal Pairs (praktik berpasangan) adalah model pembelajaran sederhana yang dapat dipakai untuk mempraktikkan suatu keterampilan atau prosedur dengan teman belajar. Dengan adanya teman belajar, siswa lebih terpacu untuk meningkatkan belajarnya serta bebas untuk berbagi ilmu atau bertanya dengan teman belajarnya. Setiap hal pasti ada yang namanya kelebihan dan kelemahan, begitu pula dalam model pembelajaran Practice Rehearsal Pairs (praktik berpasangan) ini pasti mempunyai kelebihan dan kelemahan.

\section{Peningkatan Hasil Belajar Siswa yang} Diajar dengan Menggunakan Model Pembelajaran Practice Rehearsal Pairs Pada observasi awal ke sekolah, hasil belajar siswa khususnya kelas XII IPA/IPS pada mata pelajaran Agama Hindu materi tentang ajaran Yantra, Tantra dan Mantra ajaran Nawa Widha Bhakti sebagai ajaran sikap hidup yang positif dalam kehidupan Serta banyak nilai siswa yang hanya sebatas kriteria ketuntasan minimal. Model pembelajaran yang salah kemungkinan

menjadi salah satu faktor yang mempengaruhi hasil belajar siswa. Model pembelajaran yang tidak tepat atau tidak efektif, justru akan membuat minat siswa turun terhadap mata pelajaran yang di berikan guru dalam proses pembelajaran, hal ini yang memicu hasil belajar siswa yang kurang memuaskan. Dengan adanya model pembelajaran Practice Rehearsal Pairs, dapat meningkatkan hasil belajar siswa terutama pada mata pelajaran Agama Hindu. Karena model 
pembelajaran ini menekankan pada hasil belajar kognitif, afektif, dan keaktifan, kerja sama dengan pasangan psikomotorik yang baik.

dan kedisiplinan siswa untuk mencapai

Tabel 1. Hasil belajar pada observasi awal

HASIL DAN PEMBAHASAN

\begin{tabular}{cccc} 
No & Kategori Penilaian & Frekuensi & Presentase \\
\hline 1 & A & 0 Orang & $0 \%$ \\
2 & B & 5 Orang & $25 \%$ \\
3 & C & 9 Orang & $45 \%$ \\
4 & D & 6 Orang & $30 \%$ \\
\hline & Jumlah & $\mathbf{2 0}$ Orang
\end{tabular}

Tabel 2. Hasil pengamatan kegiatan siswa pada siklus I Pertemuan 1

\begin{tabular}{cccc}
\hline No & Kriteria Penilaian & Frekuensi & Presentase (\%) \\
\hline 1 & A & 2 Orang & $10 \%$ \\
2 & B & 9 Orang & $45 \%$ \\
3 & C & 9 Orang & $45 \%$ \\
4 & D & 0 Orang & $0 \%$ \\
& Jumlah & $\mathbf{2 0}$ Orang & $\mathbf{1 0 0 \%}$ \\
\hline
\end{tabular}

Tabel 3. Hasil belajar siswa pada siklus I pada pertemuan 1

\begin{tabular}{cccc}
\hline No & Kriteria Penilaian & Frekuensi & Presentase (\%) \\
\hline 1 & A & 2 Orang & $10 \%$ \\
2 & B & 7 Orang & $25 \%$ \\
3 & C & 6 Orang & $30 \%$ \\
4 & D & 5 Orang & $25 \%$ \\
& Jumlah & $\mathbf{2 0}$ Orang & $\mathbf{1 0 0 \%}$ \\
\hline
\end{tabular}


Tabel 4. Hasil pengamatan rubrik kegiatan siswa siklus I pertemuan 2

\begin{tabular}{cccc}
\hline No & Kriteria Penilaian & Frekuensi & Presentase (\%) \\
\hline 1 & SB & 6 Orang & $30 \%$ \\
2 & B & 10 Orang & $50 \%$ \\
3 & C & 4 Orang & $20 \%$ \\
4 & K & - & $0 \%$ \\
& Jumlah & $\mathbf{2 0}$ Orang & $\mathbf{1 0 0 \%}$ \\
\hline
\end{tabular}

Tabel 5. Hasil belajar siswa pada siklus I pertemuan 2

\begin{tabular}{cccc}
\hline No & Kriteria Penilaian & Frekuensi & Presentase (\%) \\
\hline 1 & A & 7 Orang & $35 \%$ \\
2 & B & 11 Orang & $55 \%$ \\
3 & C & 2 Orang & $10 \%$ \\
4 & D & - & $0 \%$ \\
& Jumlah & $\mathbf{2 0}$ Orang & $\mathbf{1 0 0 \%}$ \\
\hline
\end{tabular}

Siswa yang mendapatkan nilai dalam kisaran indikator $\mathrm{B}$ pada siklus I pertemuan pertama berjumlah 9 orang siswa atau hanya mencapai $40,9 \%$ sedangkan pada siklus 1 pertemuan ke dua menjadi 11 orang siswa atau $50 \%$ dan jumlah siswa pada siklus I pertemuan pertama yang mendapatkan nilai dalam kisaran indikator $\mathrm{C}$ berjumlah 5 orang atau $22,8 \%$ pada siklus I pertemuan kedua hanya tersisa 4 orang atau sekitar $18,1 \%$ saja.
Dengan demikian dapat disimpulkan bahwa kegiatan belajar mengajar (KBM) pada siklus I pertemuan kedua telah mencapai target yang ditentukan yaitu $75 \%$ menjadi $81,9 \%$ bahkan melampaui target. Hal ini dapat dilihat pada peningkatan hasil belajar siswa dan kegiatan belajar mengajar (KBM) yang lebih efektif dari siklus I pertemuan pertama. 
Setelah kita melakukan atau mengerjakan sesuatu, tentu kita mengharapkan apa yang dinamakan hasil. Begitu pula dengan belajar, apa yang diperoleh dari kegiatan belajar disebut hasil belajar. Menurut Suprijono (2013) hasil belajar merupakan pola-pola perbuatan, sikap-sikap, nilai-nilai, pengertian-pengertian, apresiasi, dan keterampilan. Oleh karena itu, hasil belajar tidak hanya diperoleh dari hasil kognitif saja, tetapi juga dari afektif dan psikomotor siswanya. Sedangkan Sudjana (1989) menyatakan bahwa hasil belajar adalah kemampuan-kemampuan yang dimiliki siswa setelah ia menerima pengalaman belajarnya. Oleh karena itu hasil belajar dapat meningkatkan kemampuan atau keahlian pada diri siswa, setelah siswa itu menerima pelajaran. Perlu diketahui bahwa dalam Tabel 6. Hasil pengamatan dari observasi sampai titik ketuntasan

\begin{tabular}{cccccccc}
\hline & & \multicolumn{3}{c}{ Frekuensi } & \multicolumn{3}{c}{ Presentase (\%) } \\
\cline { 3 - 7 } No & $\begin{array}{c}\text { Kategori } \\
\text { Nilai }\end{array}$ & Observasi & $\begin{array}{c}\text { Pertemuan } \\
\text { I }\end{array}$ & $\begin{array}{c}\text { Pertemuan } \\
\text { II }\end{array}$ & Observasi & $\begin{array}{c}\text { Pertemuan } \\
\text { I }\end{array}$ & $\begin{array}{c}\text { Pertemuan } \\
\text { II }\end{array}$ \\
\hline 1 & A & 0 Org & 2 Org & 7 Org & $0 \%$ & $10 \%$ & $35 \%$ \\
2 & B & 5 Org & 9 Org & 11 Org & $25 \%$ & $45 \%$ & $55 \%$ \\
3 & C & 9 Org & 9 Org & 3 Org & $45 \%$ & $45 \%$ & $10 \%$ \\
4 & D & 6 Org & 0 Org & 0 Org & $30 \%$ & $0 \%$ & $0 \%$ \\
\hline
\end{tabular}




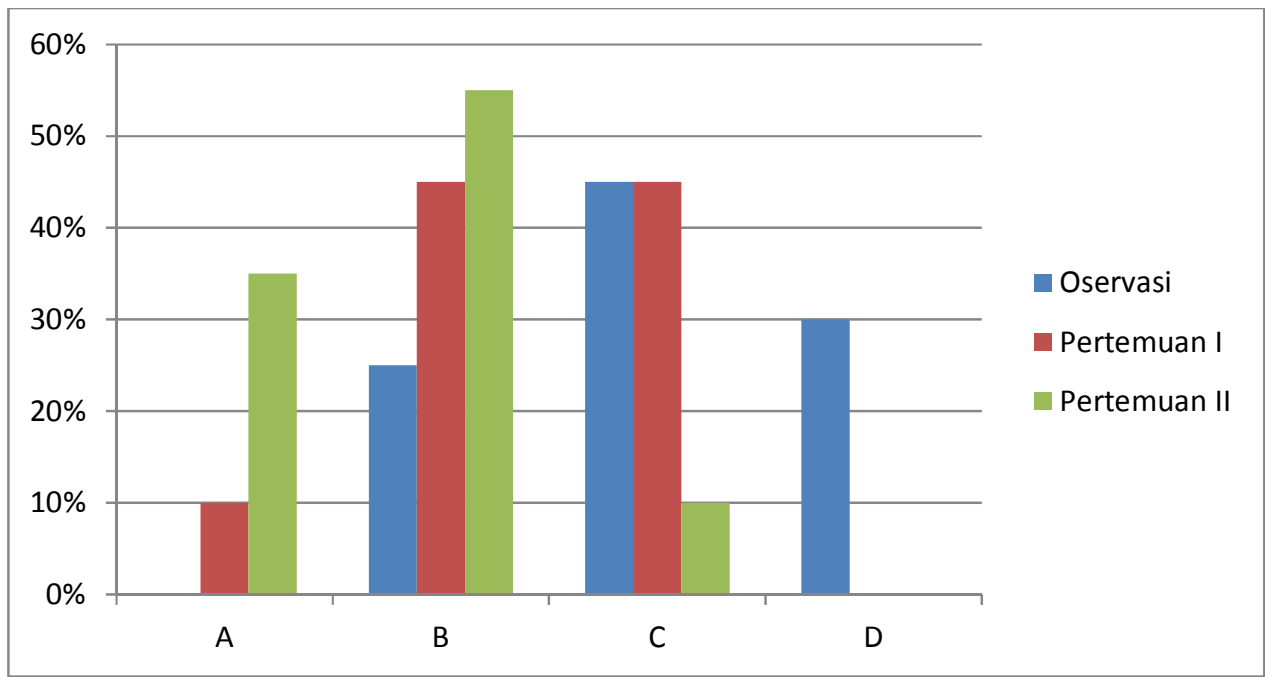

Gambar 1. Hasil pengamatan dari observasi sampai titik ketuntasan

\section{KESIMPULAN}

Berdasarkan uraian yang terdapat pada deskripsi hasil penelitian dan pembahasannya pada bab sebelumnya, maka dapat diambil kesimpulan sebagai berikut :

Penelitian tindakan kelas yang dilaksanakan selama 1 siklus 2 pertemuan dengan menggunakan model pembelajaran Practice Rehearsal Pairs telah dapat menunjukan adanya Aktivitas yang mencapai peningkatan hasil belajar siswa.

Terlihat jelas adanya peningkatan aktivitas belajar siswa dalam proses pembelajaran
Jika guru menggunakan model pembelajaran Practice Rehearsal Pairs pada mata pelajaran Agama Hindu di kelas XII SMAN 1 Randangan.

\section{DAFTAR PUSTAKA}

Slameto. 2010. Belajar dan faktor-faktor yang mempengaruhinya. Jakarta: Rineka Cipta

Sudjana. 1989. Dasar-dasar proses belajar mengajar. Sinar Baru Algensindo: Bandung.

Suprijono, Agus. 2013. Cooperatif learning. Yogyakarta: Pustaka Pelajar 